\title{
Resolving Deadlock: Why International Organisations Introduce Soft Law
}

\author{
Armin Schäfer*
}

MPIfG Journal Article

Armin Schäfer: Resolving Deadlock: Why International Organisations Introduce Soft Law. In: European Law Journal $12(2), 194$ - 208 (2006). Wiley-Blackwell

The original publication is available at the publisher's web site: http://dx.doi.org/10.1111/j.1468-0386.2006.00315.x

The MPIfG Journal Articles series features articles by MPIfG researchers and visiting scholars published in peer-reviewed journals. Max Planck Institute for the Study of Societies (MPIfG) Cologne | www.mpifg.de

Abstract: Since the mid-1990s the European Union has introduced a number of policy coordination processes that abstain from delegating or pooling sovereignty. Instead the $E U$ relies on soft law that does not legally bind governments in the same way as the Community Method used to. The literature assumes that soft law is chosen to achieve common objectives given considerable diversity among the Member States. In contrast, this paper suggests that non-binding coordination is first and foremost a means to foster compromises in the absence of substantial agreements. Three case studies demonstrate that international organisations have repeatedly relied on soft law to overcome disagreements among their members. The IMF, the OECD, and the EU introduced soft coordination at times of institutional crisis to prevent a breakdown of negotiations.

\section{Introduction}

With the Open Method of Co-ordination (OMC), the European Union added a new mode of governance to existing policy-making instruments. Instead of introducing joint competencies, the OMC consists of multilateral surveillance of national policies. Supporters of the OMC claim that it was developed to reconcile legitimacy with effectiveness, since it takes into account the diversity of national welfare states while facilitating trans-border policy learning. In contrast, this article seeks to show that EU Member States mainly use soft law in response to substantive disagreements. This mirrors earlier developments of the OECD and the IMF, where multilateral surveillance was also introduced to resolve deadlocks. In each case, Member States opted for a non-binding procedural solution to overcome competing visions of the organisations' purposes. International organisations select soft law less for its effectiveness than for its capacity to foster compromises. Based on case studies, this article juxtaposes the inauguration of soft coordination in the OECD, the IMF and the EU during the 1960s, 1970s, and 1990s respectively. In all cases Member States opted for soft law in times of 'institutional crisis' when more substantial agreements proved unattainable. As shown elsewhere, soft law policy coordination in the European Union shares many features with multilateral surveillance of the OECD and the IMF. ${ }^{1}$ Hence we can obtain a

\footnotetext{
* For helpful comments I would like to thank Irene Lynch Fannon, Andrea Lenschow, Stijn Smismans, and Wolfgang Streeck.

1 A. Schäfer, 'A New Form of Governance? Comparing the Open Method of Coordination to Multilateral Surveillance by the IMF and the OECD', (2006) Journal of European Public Policy 13 (1) 70-88.
} 
broader view on the introduction of soft law in the EU by also looking at its origins in other organisations.

A central argument of this article is that existing approaches fail to convincingly explain the choice of soft law. They are much better at understanding harder forms of delegation and legal integration. Before we proceed, we have to clarify the notion of 'soft law'. In general, we use it if there are neither binding rules nor sanctions to enforce compliance. In terms of the concept of legalisation, ${ }^{2}$ soft law scores low both on obligation and delegation, but sometimes can be quite precise. More specifically, we stick to the following definition of soft law: 'Rules of conduct that are laid down in instruments which have not been attributed legally binding force as such, but nevertheless may have certain (indirect) legal effects, and that are aimed at and may produce practical effects' ${ }^{3}$

The article is organised as follows. Section II looks at possible theoretical explanations for the choice of soft law. Recent contributions in the principal-agent framework are a good starting point to trace the question when governments decide to delegate or pool sovereignty. Since delegation always goes along with agency losses - principals cannot completely control agents - governments shy away from it if there is policy conflict. Based on this insight, section III offers a historical reconstruction of the introduction of soft law, in this case procedures of multilateral surveillance, in the OECD, the IMF, and the EU. Section IV concludes.

\section{Soft Law: A Lacuna in Integration Theory}

The European Union employs a variety of coordination mechanisms in economic and social policy. They range from the centralisation of policy-making authority in monetary policy to non-binding, soft coordination of national policies in social inclusion and pensions. Lastly, there is outright competition in some fields, such as wages and corporate taxes. Yet existing approaches fail to properly explain this variation since they either (implicitly) adopt a functionalist view on policy coordination or do not deal with this question at all. ${ }^{4}$ In particular, the Open Method of Co-ordination (OMC) uneasily situated between integration and decentralised cooperation - poses difficulties for most accounts, as they better understand delegation than non-delegation.

Most writing on the OMC does not enquire why governments chose soft coordination in employment policy. ${ }^{5}$ Instead, the focus is on the way it is operated and its (potential) effects. The turn towards 'Europeanisation,' that is, the impact of the EU on the Member States, has shifted attention away from integration, i.e. the choice for pooling or delegating sovereignty. Scholars have recently made more efforts to grasp the way the European polity functions. Since the governance approach does not aspire to explain the choice of different coordination devices, it has largely accepted the argument that soft coordination is the appropriate way to deal with Member State

${ }^{2}$ K. Abbott, R. O. Keohane, A. Moravcsik, A-M. Slaughter and D. Snidal 'The Concept of Legalization', (2000) 54: 3 International Organization 401-419.

3 L. Senden, Soft Law in European Community Law (Hart Publishing, 2004), 112 (emphasis removed from original).

${ }^{4}$ Functionalism explains the emergence of international institutions by their anticipated effects. Governments expect that permanent cooperation leads to better results than ad hoc negotiations. Cf. R. Keohane, After Hegemony. Cooperation and Discord in the World Political Economy (Princeton University Press, 1984) p. 88.

5 But see J. Goetschy, 'The European Employment Strategy: Genesis and Development' (1999) 5: 2 European Journal of Industrial Relations 117-137. 
diversity. National traditions in running the welfare state are diverse, and any common prescription would fail to do justice to this heterogeneity. ${ }^{6}$

Yet this argument is ill-suited to explain the choice of soft law for two reasons. First, if we do not look at the European Employment Strategy (EES) in isolation, but take into account the labour market recommendations of the Broad Economic Policy Guidelines, it becomes obvious that the EU does not confine itself to governance by objectives. On the contrary, these recommendations are not only specific but also resemble to a large extent those of the OECD. ${ }^{7}$ Second, national diversity may demand different solutions, yet it does not necessitate a refusal to commit governments. Content and form should be kept separate. In fact, we will see that the question of sanctions, delegation, and supranational oversight has been contested between governments and the European Commission since 1994.

Neo-functionalist accounts do not face the same problem of neglect. On the contrary, the delegation of sovereignty to the European level constitutes the core of this research programme. Over the last years, a number of authors have tried to revitalise neo-functionalism. In particular, Stone Sweet, Sandholtz, and Fligstein have offered a transaction-based account of European integration. They contend that integration is a response to societal demands for supranational rules. As cross-border transactions mount, societal actors (mainly, but not only, producers) call for common rules. In due course, governments accede to delegate competencies to the European level. ${ }^{8}$ Supranational actors have the task to make and enforce uniform market rules. Their actions, in turn, facilitate cross-border transactions that amplify demand for further supranational rules and centralised decision-making, thus generating a self-reinforcing process. However, the neo-functionalist account seems less convincing for the choice of the $\mathrm{OMC}$, since soft law neither creates uniform rules nor supranational competencies. Moreover, the EES can hardly be said to be a reaction to the mounting cross-border mobility of labour as a transaction-based approach would suggest.

In a related argument, Burley and Mattli suggest that the European Court of Justice safeguards Member State compliance to prior agreements. ${ }^{9}$ As the legal system of the European Union is complex and provides plenty of opportunities to defect, an independent agent is best suited to monitor compliance. As a matter of fact, only supranational actors enable the Member States to reap the benefits of cooperation. Thus it is rational not only to produce common rules but also to accept oversight and, in case of non-compliance, sanctions. The same argument is frequently used to corroborate the need for an independent central bank. Only an insulated authority guarantees that no bail out of individual countries takes place if they fail to adhere to prudent fiscal policies. ${ }^{10}$ Supranational actors prevent free-riding and time-inconsistent

${ }^{6}$ D. Trubek and L. Trubek, 'Hard and Soft Law in the Construction of Social Europe: the Role of the Open Method of Coordination' (2005) 11: 3 European Law Journal, 345-347.

7 J. Dostal, 'Campaigning on Expertise: How the OECD Framed EU Welfare and Labour Market Policies —and Why Success Could Trigger Failure' (2004) 11: 3 Journal of European Public Policy 440-460.

8 A. Stone Sweet and W. Sandholtz, 'European Integration and Supranational Governance' (1997) 4: 3 Journal of European Public Policy 297-317; N. Fligstein and A. Stone Sweet, 'Constructing Polities and Markets: An Institutionalist Account of European Integration' (2002) 107: 5 American Journal of Sociology 1206-1243.

9 A. Burley and W. Mattli, 'Europe before the Court: A Political Theory of Legal Integration' (1993) 47: 1 International Organization 50.

${ }^{10}$ O. Issing, 'On Macroeconomic Policy Co-ordination in EMU' (2002) 40: 2 Journal of Common Market Studies 345-358. 
behaviour of economic actors. ${ }^{11}$ Moreover, non-political decisions of autonomous agencies are supposed to provide superior solutions to technical problems. Thus an independent central bank is the best means to fight inflation. Obviously, soft law does not measure up to any of these effects inherent to delegation. Why was it nonetheless chosen for employment policy? Neo-functionalism does not seem to offer a good answer.

Moravcsik's intergovernmentalist theory champions the view that international cooperation is an attempt to arrange mutually beneficial policy coordination in the face of negative external effects of unilateral actions. ${ }^{12}$ Delegation binds parties to negotiation outcomes over time. In principle, precise rules could also credibly commit them, but uncertainty about the future makes contracts necessarily incomplete. Since governments cannot specify all possible contingencies in advance, they put supranational actors in charge of oversight and enforcement of their agreement. ${ }^{13}$ From this point of view, soft law is largely futile because national labour market policies allegedly do not produce negative spillovers. Therefore, the introduction of the employment chapter to the Treaty of Amsterdam boils down to symbolic politics. ${ }^{14}$ While Moravcsik and Nicolaïdis note that there was a conflict between rich and poor Member States and left and right parties in government, they do not elaborate on this point, as they primarily want to explain to logic of delegation. However, this article seeks to show that the choice for soft law has to be taken seriously as a way to resolve deadlocks that result from interest heterogeneity.

The last three paragraphs could easily be rephrased in-and were in fact informed by-the principal-agent language. Pollack has most systematically spelled out this account of European integration. ${ }^{15}$ He argues that EU Member States transfer power to the Commission, the Court of Justice, and the Parliament in order to minimise transaction costs. The rationale for delegation includes all of the above mentioned functions: monitoring compliance, filling in incomplete contracts, providing expert and credible regulation, and, in addition, setting the formal agenda for legislation. ${ }^{16}$ In contrast to Moravcsik, however, Pollack claims that principals can never fully control agents and that the latter will exploit this leeway to advance integration. Agency loss, i.e. the degree of discretion for supranational actors, is a function of uncertainty about future behaviour and, accordingly, the potential for defection among the principals. Another point is worth noting. Delegation is more likely if 'the degree of [policy] conflict is low both among the principals and between principals and their agents'. ${ }^{17}$ The next section seeks to show that governments shied away from delegating sovereignty when there were substantial disagreements. Soft coordination was a way to overcome conflicting interests in the OECD, the IMF, and the European Union.

${ }^{11}$ G. Majone, 'Temporal Consistency and Policy Credibility: Why Democracies Need Non-Majoritarian Institutions' (1996) EUI Working Paper, RSC No. 96/57.

12 A. Moravcsik, The Choice for Europe. Social Purpose and State Power from Messina to Maastricht (UCL Press, 1998) p. 36.

13 Moravcsik, op. cit. note 12 supra, at 73.

14 A. Moravcsik and K. Nicolaïdis, 'Explaining the Treaty of Amsterdam: Interests, Influence, Institutions' (1999) 37: 1 Journal of Common Market Studies 62.

15 M. Pollack, The Engines of European Integration. Delegation, Agency, and Agenda Setting in the EU (Oxford University Press, 2003).

${ }^{16}$ Pollack, op. cit. note 15 supra, at 25.

17 Pollack, op. cit. note 15 supra, at 34. 


\section{Procedural Answers to Policy Conflicts: Multilateral Surveillance in International Organisations}

Why do governments choose soft law to deal jointly with problems rather than more binding forms of cooperation? In the EU context, it is commonly held that governments opted for the EES and later the OMC because soft coordination creates opportunities for deliberation, systematic comparisons, and learning. ${ }^{18}$ Similar arguments have been made for the $\mathrm{OECD}^{19}$ although recent research casts doubts on this organisation's effectiveness in influencing national policies. ${ }^{20}$ Yet whatever effects we observe, they need not be the reason for the choice of a certain instrument. As the next parts of this article seek to show, governments relied on soft law to overcome their disagreements in very different contexts. If substantive agreements are impossible or hard to attain, non-binding procedures become an option negotiators can draw on. Soft law may in due course turn into a more solid form of cooperation and foster its own unanticipated dynamic, but during negotiations its main virtue is to avoid deadlock.

\section{A OECD: If You Cannot Bind Governments, Watch Them!}

The first organisation to introduce multilateral surveillance was the OECD. It began to monitor national economic policies at its inception in 1961. However, we even find an earlier version of surveillance in its predecessor organisation, the Organisation for European Economic Cooperation (OEEC). In 1947, when the US government announced the increase in financial aid to post-war Europe with the European Recovery Program (ERP) - better known as Marshall Aid - it also called for permanent cooperation of the recipient states. France and Great Britain took the lead and organised an international conference in July 1947. At this Paris conference the participant governments decided to establish the OEEC. ${ }^{21}$ The allocation of Marshall Aid was the most important task for the organisation but, more generally, it strove to facilitate European reconstruction and to increase trade among the recipient states, which faced severe balance of payments difficulties. Allocating the funds turned out to be an arduous task that did not foster a cooperative climate as the US government had hoped, but rather instigated prolonged haggling between national administrations. ${ }^{22}$ However, in due course the OEEC managed to liberalise trade among European states.

The most successful part of the OEEC was the European Payments Union (EPU), created in July 1950. The EPU operated a clearing mechanism that allowed settling debts and credits among all Member States, finally moving away from bilateral clearing that had hampered intra-European trade for the past years. Reviving trade helped closing the dollar gap and thus diminished the importance of protective import quotas. The OEEC states also subscribed to a Code of Liberalisation that outlined a stepwise

18 J. Zeitlin, 'Introduction: Governing Work and Welfare in a new Economy: European and American Limits', in J. Zeitlin and D. Trubek (eds), Governing Work and Welfare in a New Economy. European and American Experiments (Oxford University Press, 2003) p. 5.

19 H. Aubrey, Atlantic Economic Cooperation. The Case of the OECD (Frederick A. Praeger, 1967) p. 144.

${ }^{20} \mathrm{~K}$. Armingeon and M. Beyeler, The OECD and European Welfare States (Edward Elgar, 2004).

${ }^{21}$ A. Milward, 'The Committee of European Economic Co-operation (CEEC) and the Advent of the Customs Union', in: W. Lipgens (ed.), A History of European Integration. Volume 1: 1945-1947 (Clarendon Press, 1982).

22 T. Schelling, 'American Foreign Assistance' (1955) 7: 4 World Politics 606-626. 
reduction of import quotas and tariffs until 1955. Though there were at times difficulties, the EPU worked well and contributed to the expansion of trade and European reconstruction in general. ${ }^{23}$

The European Payments Union is important because it first established Member State surveillance. If a member's balance of payments deteriorated and threatened to exhaust the available credit, it was the task of the Managing Board to issue recommendations on how to deal with the economic crisis without endangering the functioning of the EPU. Accordingly, Member States were obliged to transmit all required information about their economic policies to the Managing Board. Early on, the EPU had to prove its effectiveness when, in the aftermath of an ambitious trade liberalisation, West Germany's balance of payments aggravated rapidly. To deal with such problems, the Managing Board established a number of steps that until today constitute the core of multilateral surveillance. First, it sent two experts on a mission to Germany, who had to evaluate the economic situation and the appropriateness of the government's actions. Second, it issued a number of policy recommendations that were meant to support the trade balance. Third, there was a hearing of government representatives and of the national central bank. The national delegation was required to appear at the meeting of the Managing Board for questioning, to comment on the experts' report, and to explain government policies. ${ }^{24}$ However, what distinguished this early monitoring from later forms of multilateral surveillance was that the Managing Board had the authority to license short-term credits. Positive sanctions increased the incentive for national governments to comply.

The achievements of the EPU were such that one of its architects anticipated in 1957 that it would soon fall prey to its successes. ${ }^{25}$ Indeed, good times ended for the EPU and the OEEC in 1958. Most of its Member States moved towards currency convertibility and the Treaty of Rome came into force establishing a new forum for political cooperation. Both events diminished the importance of the OEEC. First, with the main economic problems of Western Europe being solved, the IMF finally took up the role assigned to it 14 years earlier at Bretton Woods. In the same year, the European Payments Union was dissolved. Second, the OEEC members split into 'the Six and the Seven': ${ }^{26}$ Belgium, France, Germany, Italy, Luxembourg, and The Netherlands joined the European Economic Community (EEC), whereas Austria, Denmark, Great Britain, Norway, Portugal, Sweden, and Switzerland formed the European Free Trade Association (EFTA). The remaining OEEC countries, Greece, Ireland, Island, and Turkey, became members of neither organisation. As a result, the OEEC needed a new purpose.

The split between the six and the seven reflected opposing approaches to European integration and also different economic interests. First, while the six supported pooling and delegation of sovereignty and saw themselves on a road to political union, the seven favoured intergovernmental forms of cooperation and a large free trade area. Second, the OEEC's Code of Liberalisation included the most-favoured-nation rule among its

${ }^{23}$ W. Asbeek Brusse, 'Liberalising Intra-European Trade', in R. Griffiths (ed.), Explorations in OEEC History (OECD, 1997).

${ }^{24}$ B. Eichengreen, Reconstructing Europe's Trade and Payments. The European Payments Union (University of Michigan Press, 1993), p. 32.

${ }^{25}$ R. Triffin, Europe and the Money Muddle. From Bilateralism to Near-Convertibility, 1947-1956 (Yale University Press, 1957), 208.

${ }^{26}$ U. Kitzinger, 'Europe: The Six and the Seven', (1960) 14: 1 International Organization 20-36. 
members. France in particular hoped to get rid of this obligation and to weaken the British influence. Britain, in turn, saw the EEC states as discriminating against nonmembers. The USA had strongly supported closer European cooperation after the war, but now looked for a broader, transatlantic organisation to be able to exert influence. ${ }^{27}$ Hence the OEEC members decided to reform the organisation, and in 1960 assigned the task of drafting a proposal to the 'Group of Four' (Wise Men). ${ }^{28}$

Distilling the views of the 20 governments involved in the discussion proved difficult. They disagreed on almost every aspect of the organisation: (1) its competencies and the degree of legalisation: voluntarism versus obligation; (2) the scope of activities and the demarcation against the work of the EEC, the GATT, and the IMF; (3) a European or Atlantic focus. While the United States and France favoured a loose form of cooperation that did not infringe sovereignty, Switzerland and Sweden supported a stronger organisation, including some pooling and delegation. The EFTA states and the North American states wanted the new organisation to deal with trade policy and discriminatory practices, but the EEC members opposed any obligation that interfered with the move towards a customs union. France wanted to do away with the Code of Liberalisation; Germany preferred to keep it. ${ }^{29}$

In the light of these policy conflicts, a substantive agreement could not be achieved. Instead, the Wise Men had to look for compromises. One element that national governments could agree upon was to continue the consultation practice of the OEEC. However, without the Code of Liberalisation there were no longer any binding goals involved, and the economic reviews would mainly serve to exchange opinions: 'Under the annual review procedure each country submits its economic situation and policies to the examination of all its partners. Ample opportunity is thus provided for discussion of major problems, and each country is confronted with an informed view on the impact of its policies on its neighbours' ${ }^{30}$

At the end, all governments could consent to use multilateral surveillance to coordinate economic policies. On 14 December 1960, they signed the Convention of the new Organisation for Economic Cooperation and Development that came into force in $1961 .^{31}$ Many of its goals were general and vague. The form of cooperation within the OECD was clearly intergovernmental and it did not produce any legislation. However, the OECD set the example for non-binding consultation procedures that Wallace calls 'OECD technique' in the EU context. ${ }^{32}$ Hence, disagreements in substance do not end cooperation. National governments instead opt for procedural solutions. As we will see for the IMF and the EU, too, the choice of multilateral surveillance falls far short of binding law, but it maintains cooperation. Although it cannot legally commit governments to prudent policies, it rests on moral persuasion and peer pressure. Whatever it effects are, however, soft law often emerges as a way to overcome conflicting views in substance.

\footnotetext{
${ }^{27}$ Aubrey, op. cit. note 18 supra, 22-23.

28 The four were Sir W. Randolph Burgess, Bernard Clappier, Paul Gore-Booth, and Xenophon Zolotas.

29 M. Camps, Britain and the European Community 1955-1963 (Oxford University Press, 1964), pp. $268-273$.

${ }^{30}$ W. R. Burgess, B. Cappier, P. Gore-Both and X. Zolotas, A Remodelled Economic Organisation. A Report by the Group of Four (Organisation for European Economic Development, 1960), p. 20.

31 OECD, Convention on the Organisation for Economic Co-operation and Development. Paris, 14 December 1960.

${ }^{32}$ H. Wallace, 'The Institutional Setting: Five Variations on a Theme', in H. Wallace and W. Wallace (eds), Policy-Making in the European Union (Oxford University Press, 2000), p. 32.
} 


\section{B IMF: Adapting to Changing Circumstances}

The IMF introduced multilateral surveillance in response to a profound disagreement among its members on how to react to the breakdown of the Bretton Woods system of adjustable pegs. The IMF Articles of Agreement after the second amendment could barely hide that they were bridging opposing ideas about the international monetary system. The core controversy was between the proponents of fixed and floating exchange rates.

Bretton Woods had envisioned a symmetrical exchange rate system where all currencies would be fixed against gold, but it quickly became a 'fixed-rate Dollar standard'. ${ }^{33}$ This development had a direct impact on the question: who adjusts? In an $N$-country exchange rate system, only $N$-1 independent balance of payments instruments are needed, because if all states but one achieve an equilibrium in their trade balances, the $N$ th country will by implication also be in equilibrium. ${ }^{34}$ With the Dollar standard, it was up to all countries except the USA to adjust. Adjustment rested on three instruments: the exchange rate, fiscal policy, and monetary policy. In turn, the USA ran a large trade deficit to ensure liquidity in the international monetary system, and promised to convert foreign-held Dollar reserves into gold. Moreover, since the USA virtually turned into the world's central bank it had to pursue anti-inflationary policies to keep the exchange rate system stable. Figure 1 summarises the de facto functioning of the Bretton Woods system.

The system ran into problems when governments became unable (or unwilling) to use the adjustment mechanisms and US inflation rose during the Vietnam War. Between 1948 and 1967 there were only 15 changes in par values of the OEEC countries, none

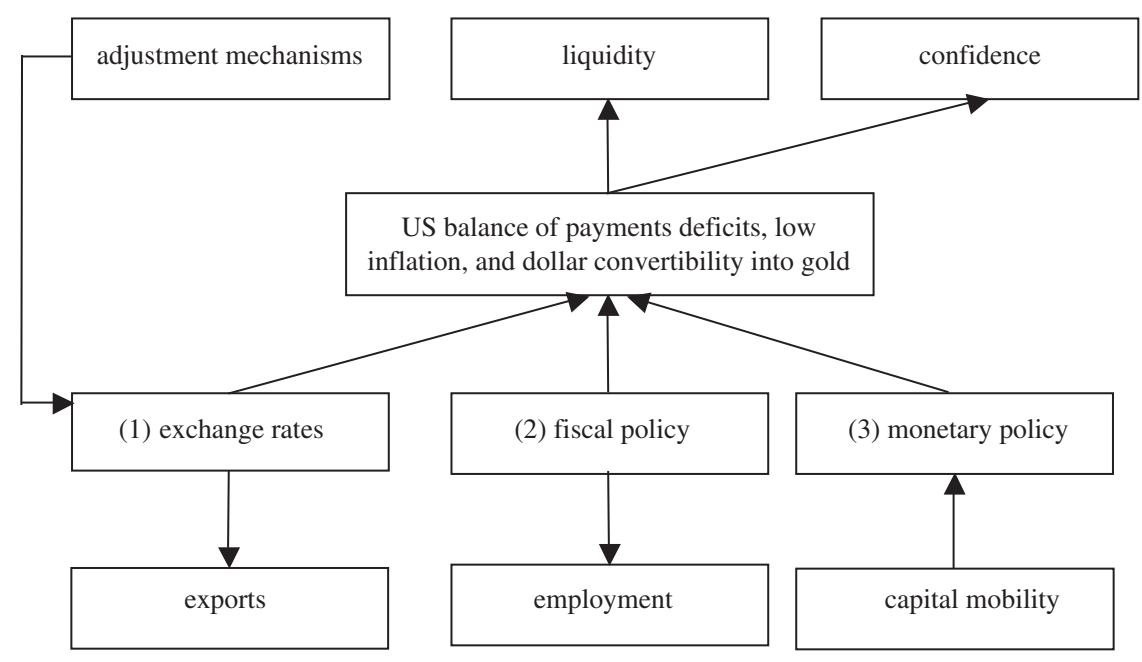

Figure 1. The Dollar Standard, 1950-1971.

${ }^{33}$ R. McKinnon, 'The Rules of the Game: International Money in Historical Perspective', (1993) 31 Journal of Economic Literature 15.

${ }^{34}$ R. Mundell, 'The Redundancy Problem and the World Price Level', in R. Mundell (ed.), International Economics (Macmillan, 1968), p. 195. 
of those after $1961 .^{35}$ Governments consciously tried to avoid exchange-rate changes because of the effects on inflation, the price of imported goods, credibility of government policies, and export opportunities. As long as unemployment and capital mobility were low, two internal adjustment mechanisms remained: fiscal and monetary policy. Yet with rising (imported) inflation, governments of surplus countries were less ready to utilise fiscal policy to stimulate the economy; and a restrictive fiscal policy meant rising unemployment of deficit countries. Greater capital mobility, on the other hand, increased the costs of a loose monetary policy. Lower interest rates would not only stimulate investment but also cause capital flight — and the magnitude of the latter was on the rise. In short, adjustment mechanisms vital for the functioning of the Dollar standard soared during the 1960s.

The mounting balance of payments deficits of the United States and the incapacitation of adjustment mechanisms undermined confidence in the system. This led to a convertibility crisis known as the Triffin dilemma. As a result of continuous deficits, US gold reserves declined relative to outstanding dollar liabilities. During the 1960s it became clear that the US authorities could no longer cover those liabilities. Accordingly, after some turbulent years, the Bretton Woods system came to an end in 1971/73. US inflationary policies and a deep conflict over who should adjust dealt the final blow to a system that had grown inflexible. ${ }^{36}$

The advent of floating exchange rates put pressure on the IMF since the Articles of Agreement rested on the assumption of fixed exchange rates. Some of its most important members openly violated IMF principles. Hence, after 1973, it was clear that the international monetary system had to be reformed. While the US government demanded more flexibility, many European countries favoured a return to fixed exchange rates with symmetric adjustment mechanisms. Ever since President de Gaulle, France had objected to the privileged position of the United States in the international monetary system. The French government called for a return to a system based on fixed but adjustable par values and considered floating rates 'wrong and dangerous'. Accordingly the core controversy was on Article IV of the IMF charter, which defined fixed exchange rates as the guiding principle of the international monetary system. On March 14, 1975, the IMF presented its first proposal for a revision of this article. ${ }^{38}$ While maintaining the goal of fixed exchange rates, it accepted the possibility of floating rates under special circumstances. In addition, the IMF proposed to widen the margin of admissible par value fluctuations and to allow for preventive exchange rate adjustments. Hence the system should be kept in principle, but dealt with more flexibly. However, for differing reasons, both the French and US governments rejected this proposal.

The breakthrough was achieved later that year in November, during a summit of the heads of state and government of France, Germany, Great Britain, Italy, Japan, and

35 J. Horsefield and M. de Vries, The International Monetary Fund 1945-1965. Twenty Years of International Monetary Cooperation. Volume II: Analysis (International Monetary Fund, 1969), pp. 116-121.

${ }^{36}$ M. Bordo, 'The Bretton Woods International Monetary System: A Historical Overview', in M. Bordo and B. Eichengreen (eds), A Retrospective on the Bretton Woods System (The University of Chicago Press, 1993), p. 80 .

37 Provisions Regarding Par Values and Exchange Stability Under Article IV by the Executive Director for France, Jacques Wahl, April 9, 1975. Reprinted in M. de Vries, The International Monetary Fund 1972-1978. Cooperation on Trial. Volume III: Documents (International Monetary Fund, 1985), p. 736.

${ }^{38}$ Staff Draft of and Commentary on the Amendment of Article IV, March 14, 1975. Ibid., 287-295. 
the United States at the Chateau de Rambouillet in France. The compromise tolerated flexible and fixed exchange rates, but did not tie Member States to any one system any longer. ${ }^{39}$ The negotiators called for a 'stable system of exchange rates' without defining this phrase precisely. In fact, France had demanded a 'system of stable exchange rates'. While the new formulation could be associated with the hope for fixed exchange rates, it did not bind governments. ${ }^{40}$ Since it was not unambiguously clear which behaviour would be compatible with a stable system of exchange rates, the IMF had the task to monitor Member States' policies. More precisely, the Fund was asked to exercise 'firm surveillance' of their exchange rate policies (Article IV, Section 3(a) and (b). It had to report on national policies, which were then subject to discussion in the Executive Board. However, IMF Member States introduced multilateral surveillance less for its alleged effectiveness, but as an answer to the substantial disagreement over the shape of the international monetary system. As the IMF historian observes:

It is clear from the record of the deliberations on the Second Amendment in the mid-1970s that the Fund's governors did not agree on the precise meaning of 'firm surveillance' and even that the phrase was introduced as a substitute for agreement on a more precise reform of the exchange rate system. Those (notably U.S. officials) who sought a flexible system in which exchange rates could adjust freely in response to market forces saw surveillance as a means of discouraging countries from manipulating exchange rates in opposition to market pressures. Those (notably French officials) who sought greater stability in exchange rates saw it as a means of encouraging countries to adopt economic policies that would ensure such stability. Both sides recognised that the principles and procedures of surveillance would have to be worked out gradually through experience. ${ }^{41}$

In April 1976, the Board of Governors of the IMF agreed to the proposed changes. The second amendment of the Articles of Agreement came into force two years later, in April 1978. Ever since, the IMF has conducted multilateral surveillance much like the OECD and, to date, the European Union does.

The 1976 treaty reform characterises the transition form a rule-based to a discretionary international monetary system. States can choose between fixed or floating exchange rates or opt for regional currency arrangements. ${ }^{42}$ In such a system, economic policy coordination is harder to attain since exchange rate stability does no longer indicate prudent domestic policies and there is no simple measure to detect competitive devaluations ('dirty floating'). As a consequence, the scope of multilateral surveillance has been broadened over the years. It has by now become a thorough examination of national economic policies. Interface management has given way to the monitoring of domestic policies. Yet the growing importance of multilateral surveillance has not been paralleled by a higher degree of delegation of sovereignty. On the contrary, while the IMF reports on national policies, it has no power to enforce its recommendations. In

39 The final formulation was as follows: 'Under an international monetary system of the kind prevailing on January 1, 1976, exchange arrangements may include (i) the maintenance by a member of a value for its currency in terms of the special drawing right or another denominator, other than gold, selected by the member, or (ii) cooperative arrangements by which members maintain the value of their currencies in relation to the value of the currency or currencies of other members, or (iii) other exchange arrangements of a member's choice'. IMF, Articles of Agreement, Article IV, Section $2 \mathrm{~b}$.

${ }^{40}$ L. Pauly, Who Elected the Bankers? Surveillance and Control in the World Economy (Cornell University Press, 1997), p. 104.

41 J. Boughton, Silent Revolution. The International Monetary Fund 1979-1989 (International Monetary Fund, 2001), p. 68.

${ }^{42}$ M. Guitián, 'The Unique Nature of the Responsibilities of the International Monetary Fund' (1992) IMF Pamphlet Series 46, 9-10. 
practice, multilateral surveillance leaves the IMF fairly toothless with members who do not need its financial resources. ${ }^{43}$ Compliance with the Fund's recommendations remains essentially voluntary. ${ }^{44}$ Multilateral surveillance was chosen as a compromise procedure to bridge different opinions about the proper functioning of the international monetary system and it cannot bind governments.

\section{EU: Deliberation as a Default Option}

The degree to which supposedly power-jealous states pooled and delegated sovereignty distinguished the European Union from other international organisations from the beginning. The Treaty of Rome gave a strong mandate to supranational actors. The European Commission, the European Court of Justice and, later the European Parliament became involved in the formulation, administration, and legal oversight of European policies. While the Commission had the exclusive right to initiate policies, the Court of Justice held the authority to interpret Community law. The Community Method has proven tremendously effective in promoting integration. Yet it has come under attack in recent years. First, the Community Method was not extended to foreign policy or justice and home affairs when they were launched to EU policymaking with the Maastricht Treaty. Second, the employment chapter of the Amsterdam Treaty introduced a potential rival to the Community Method, which after the March 2000 Lisbon summit was dubbed the Open Method of Co-ordination. The next few paragraphs show that the introduction of multilateral surveillance in employment policy was an answer to different ideas about the proper involvement of the EU in this policy field.

In the aftermath of the Maastricht summit, European integration was in crisis. Danish voters in 1992 rejected the Treaty in a referendum, and the French accepted it by a tiny majority only. At the same time, the European economy turned sour and unemployment rose again. There was a widespread notion that integration was too exclusively focused on market integration, disregarding unemployment as the most pressing problem. The permissive consensus supporting integration was at risk. Accordingly, centre-left governments called for a European approach to fight unemployment without, however, granting more power to distant 'Brussels bureaucrats'. Thus at the Copenhagen summit in 1993, the European Council instructed the Commission to produce a White Paper. It was asked to spell out a strategy for higher growth, competitiveness, and employment. The Commission's report became known as the 'Delors White Book'.

The next step towards a European employment initiative came with the Essen summit in 1994. Heads of state and government agreed on a number of non-binding objectives to fight unemployment. These included investing in human capital (up-skilling of the workforce), increasing the employment-intensiveness of growth, reducing non-wage labour costs, improving the effectiveness of employment policy by moving from passive to active labour market policy, as well as supporting groups particularly hard hit by unemployment. However, the Essen employment procedures were mainly meant to

${ }^{43}$ M. Kahler, 'Organization and Cooperation: International Institutions and Policy Coordination' (1988) Journal of Public Policy 8 (3-4), 386.

${ }^{44}$ C. Goddard and M. Birch, 'The International Monetary Fund', in C. Goddard et al. (eds), International Political Economy. State-Market Relations in the Changing Global Order (Lynne Rienner, 1996), p. 222. 
fend-off more ambitious proposals of the ascending social democratic majority in the European Council. ${ }^{45}$ They covered up a party-political dispute on the question how to generate employment growth.

Because of this policy conflict, none of the objectives was legally enforceable or entailed the delegation of sovereignty. The governments most sceptical of a European employment policy knew that a binding agreement would make for unduly Commission interference in domestic policy making. Accordingly, they fought for a soft law approach. As a result, Member States were merely urged 'to transpose these recommendations in their individual policies into a multi-annual program having regard to the specific features of their economic and social situation' ${ }^{46}$ The European Commission and the Labour and Social Affairs, as well as Economic Financial Affairs Council, were asked to monitor national developments and report annually to the European Council about progress. Hence, core elements of the $\mathrm{OMC}$ - common objectives, national implementation, and surveillance by the Commission and Member Stateswere already in place in 1994. Content and form followed from a disagreement in substance and a consensus to limit obligation. A soft coordination padded with mutual monitoring served both.

Social democratic governments particularly supported a higher EU profile in tackling unemployment during the Intergovernmental Conference leading to the Amsterdam Treaty. Still, until early 1997, chances that the negotiations would lead to an agreement were slim as conservative governments in Great Britain, France, and Germany opposed even this limited approach. Only after the elections in the first two countries, which brought New Labour and the French socialists to power, did an agreement became possible. In the end, not even the Kohl government was keen on blocking treaty reform for an issue considered of minor relevance. It wanted to make sure, though, that any transfer of power to the European Commission would be strictly limited. However, even among centre-left governments there was a disagreement over the EES. Jospin and Blair supported quite different labour market policies domestically, and both strove to Europeanise those. And while most social democratic governments generally were in favour of an employment chapter, they insisted on the principle of subsidiarity since they were afraid that otherwise the credit for fighting unemployment - an electoral asset for centre-left parties - would go to the EU. ${ }^{47}$

In the end, employment became part of the Amsterdam Treaty. The disagreement in substance-how to fight unemployment and whether this would require EU competencies - created the soft coordination of the European Employment Strategy. The EES was not a tool chosen primarily because it was the most promising means to an end, but rather because it facilitated a compromise between supporters and opponents of the employment chapter. Agreement rested on two conditions: there would neither be a transfer of competencies to the European level nor an increase in spending. ${ }^{48}$ While the supporters could claim to have successfully fought for an employment chapter, its opponents made sure it remained largely toothless.

Since the amended treaty would only be ratified in 1999, governments decided to have a special summit on employment in 1997. Because it took place in Luxembourg,

${ }^{45}$ S. Hix and C. Lord, Political Parties in the European Union (Macmillan Press, 1997), p. 194.

46 European Council, Presidency Conclusions, Essen, 9 and 10 December 1994.

47 R. Ladrech, 'The Left and the European Union', (2003) 56 Parliamentary Affairs 119.

48 Goetschy, op. cit. note 5 supra, 125. 
the European Employment Strategy was baptised the 'Luxembourg process'. Consciously modelled on the Maastricht convergence process, the employment chapter of the Amsterdam Treaty introduced the following cycle of multilateral surveillance:

(1) every year, members states would agree on Employment Guidelines specifying common objectives;

(2) each government would draw up a National Action Plan (NAP) detailing the strategy for how it would seek to achieve these goals;

(3) based on a Commission draft, the Council and the Commission would publish the Joint Employment Report which would assess and evaluate Member States' NAPs as well as their policies;

(4) the European Council would annually review these reports and, if appropriate, modify the Guidelines.

While this procedure mimicked the convergence programme, it refrained from introducing sanctions. The Luxembourg process tried to compensate for its limited legal weight by putting a stronger emphasis on the commitment made by governments. They were asked to draw up a NAP to detail their approach to fighting unemployment. This document could be used thereafter to compare word and action. This Commission hoped to gain influence on national policies by reminding reluctant governments of their prior commitment.

However, at the Luxembourg summit, no consensus could be reached on defining a target for unemployment as a counterpart to those concerning public deficits, inflation, and debts. The Commission proposed a more rigorous set of employment guidelines and urged the Member States to accept clearly specified quantitative targets, but could not overcome their resistance. Reducing employment policies to a voluntary opportunity for learning without obligatory targets facilitated support for it. In the end, such diverse governments as those led by Jospin, Blair, Aznar, and Kohl were able to accede to the thus-conceived Employment Strategy. In sum, the turn towards soft law in employment policy ensured that the negotiations were not deadlocked over substantive disagreements.

The goals of European integration have become more contested in recent years. While centrist parties generally remain in favour of integration, the implicit consensus over which policies can and should be handled jointly has vanished. As Hooghe, Marks, and Wilson show, there is a clear left-right division on policies that regulate capitalism: The left supports European competencies for environment, cohesion, and employment policies; the right opposes them. ${ }^{49}$ The OMC was a social democratic attempt to craft a social policy mandate onto the existing economic constitution. At the Lisbon summit in March 2000, centre-left coalitions governed in eleven countries. They seized the opportunity to turn the EES into a general governance tool called the Open Method of Co-ordination. ${ }^{50}$ This allegedly new method was thereafter extended to a whole range of policies (e.g. social inclusion, research and development, pensions) where a

49 L. Hooghe, G. Marks and C. J. Wilson, 'Does Left/Right Structure Party Positions on European Integration?', in G. Marks and M. Steenbergen (eds), European Integration and Political Conflict (Cambridge University Press, 2004).

${ }^{50}$ D. Trubek and J. Mosher, 'New Governance, Employment Policy, and the European Social Model', in Zeitlin and Trubek, op. cit. note 17 supra. 
treaty base was lacking, but governments still sought joint initiatives. As the OMC proliferated, the European Council devised more ambitious aims for the EU. The so-called Lisbon Strategy announced the goal to make the EU the world's most dynamic and competitive economy, with full employment and more and better jobs. ${ }^{51}$ Yet, neither the goals nor the procedures were legally binding; they instead rested on voluntary compliance. Growing membership increases interest heterogeneity within the European Union and makes substantive agreements more unlikely. As a consequence, governments could rely on soft law even more often now than in the past, because in this way they can 'agree to disagree'. Yet we should not conceive of these compromises as a functionally necessary. They are an answer to policy conflicts and not primarily adopted to solve problems.

\section{The Virtues of Soft Law}

The organisations studied above introduced soft law procedures at times when their Member States could not agree on the purpose of the organisations. In the OEEC, the survival of the organisation itself was at stake since different governments championed very different forms of cooperation. Only diminishing the obligations that came with membership made the transformation of the OEEC into the OECD possible. As there were conflicting ideas about the purpose of the new organisation, the Member States did not agree on delegating authority. The OECD could not rely on binding law any longer, but became an expert organisation and 'ideational artist' geared towards policy advice. ${ }^{52}$ In a similar vein, the Keynesian consensus that had existed during the Bretton Woods negotiations dissolved in the 1970s. IMF members held opposing views on how the international monetary system would function best. The Europeans generally favoured fixed par values, while the United States preferred floating exchange rates. Since there is no easy compromise between these two positions, the negotiations over the reform of the Articles of Agreement lasted several years. The final text consciously employed an imprecise language, and asked Member States to endeavour to support a 'stable system of exchange rates.' However, it was neither clear what kind of behaviour would indicate non-compliance nor were there any consequences but appeals to national governments. In contrast to a rule-based system, the IMF certainly lost influence. Finally, the European Union opted for soft law in employment policy because in the first half of the 1990s there was no agreement on which policies would be most appropriate to fight unemployment or on the need for EU competencies. There was a party-political conflict between social democratic and conservative governments but also among centre-left parties. Competing national opinions on labour market policies did not translate without difficulty into joint European policies. The European Employment Strategy became possible after its ambitions and the supranational involvement had been scaled down considerably. Once governments were certain that the EU could not force them to adopt policies against their will, they consented to the employment chapter. In sum, international organisations do not introduce multilateral surveillance because of its proven effectiveness but rather when no substantial agreement is obtainable.

${ }^{51}$ European Council, Presidency Conclusions, Lisbon, 23 and 24 March 2000.

${ }_{52}$ M. Marcussen, 'Multilateral Surveillance and the OECD: Playing the Idea Game', in Armingeon and Beyeler, op. cit. note 19 supra. 


\section{Conclusion}

Hug and König use the two-level game concept to explain why the ratification of the Amsterdam Treaty went smoothly. ${ }^{53}$ Negotiating governments had learned from the Maastricht experience that domestically controversial issues endanger ratification. As a consequence, if there was substantial disagreement among the negotiators on policy areas, issues were removed from the Commission draft during the Intergovernmental Conference. At the end of this process of 'issue subtraction' only those topics entered the Amsterdam Treaty that had aroused little controversy. However, this article argues that there is another possibility besides removing issues, namely, scaling down their impact. That is what happened in employment policy. Rather than subtracting the employment chapter as a whole, governments watered it down. At the end, everyone was able to agree to a non-binding appeal to good will.

More generally, Chayes and Chayes point out that negotiations do not necessarily fail because of different preferences of the negotiators. ${ }^{54}$ There are ample ways to compromise and, over the years, we have seen many of those in the European Union. Techniques to resolve deadlock include opt-outs or a long phasing-in of policies. Another possibility is to define only general goals and leave the exact meaning unspecified. It will then be defined through the practical application. Governments did not know in detail what effects OECD Economic Surveys, IMF Article IV Consultations, or the European Employment Strategy were going to have. However, they were sure that soft law would not infringe their room for manoeuvre too strongly.

Since the Maastricht Treaty provided a number of opt-outs in social policy and European Monetary Union, differentiated integration has been used a number of times to resolve deadlock. With the Amsterdam Treaty and later the OMC this tool has become less relevant. It is no longer variable geometry that facilitates compromises, but variable contents. If agreements are not binding, it is much easier even for opposing governments to support them.

Theoretical accounts of European integration see supranational rules and the degree of delegation as a response to mounting societal pressure for common rules, a way to handle incomplete contracting, or a means to achieve efficient bargaining outcomes. Yet they have more difficulties in answering why governments would choose soft law since it does not conform to any of these expectations. The principal-agent framework suggests that delegation is rational if the reduction in transaction-costs outweighs agency losses, if future defection is likely, and if policy conflicts among the negotiators are low. Inverting this logic we can argue that governments shy away from delegation if they fear that supranational agents misuse their autonomy or if there is a deep disagreement. In these cases cooperation does not necessarily end, but it may take the form of soft law. Introducing multilateral surveillance is but one technique to avoid the failure of international negotiations. Taking this insight into account would prevent some of the writing on the OMC from making heroic assumptions on the reason why it has become so popular among governments in recent years.

First submitted August 2005

Final revision accepted November 2005

\footnotetext{
${ }^{53}$ S. Hug and T. König, 'In View of Ratification: Governmental Preferences and Domestic Constraints at the Amsterdam Intergovernmental Conference', (2002) 56: 2 International Organization 447-476.

${ }^{54}$ A. Chayes and A. H. Chayes, 'On compliance' (1993) 47: 2 International Organization, 184.
} 